\title{
Blood Cell Alteration in Triploid Brook Trout Salvelinus fontinalis (Mitchill)
}

\author{
T. WŁASOW ${ }^{1}$, H. KUZMINSKI ${ }^{2}$, P. WOZNICKI $^{1}$, E. ZIOMEK ${ }^{1}$ \\ ${ }^{1}$ Department of Evolutionary Genetic, University in Olsztyn, Olsztyn -Kortowo, Poland \\ ${ }^{2}$ Inland Fisheries Institute, Salmonid Research Department, Rutki, Zukowo, Poland \\ Received May 25, 2003 \\ Accepted February 11, 2004 \\ Abstract
}

Własow T., H. Kuzminski, P. Woznicki, E. Ziomek: Blood Cell Alteration in Triploid Brook Trout Salvelinus fontinalis (Mitchill). Acta Vet. Brno 2004, 73: 115-118.

The subject of the experiment were blood cells originating from a diploid (2n) and a triploid (3n) brook trout Salvelinus fontinalis (Mitchill). Both the diploid and the triploid fish originated from the same batch of spawn. The triploids of brook trout were obtained through the application of a hydrostatic pressure shock of $9500 \mathrm{psi}\left(65.5 \cdot 10^{3} \mathrm{kPa}\right)$ for $5 \mathrm{~min}$ to eggs $20 \mathrm{~min}$ following fertilization at a temperature of $10{ }^{\circ} \mathrm{C}$. The diploids were not subject to shock. The $3 \mathrm{n}$ and $2 \mathrm{n}$ fingerling of brook trout were reared under the same conditions (environment, feeding) in parallel pools. Blood was sampled for smears, which, in combination with the prepared chromosomes, were used to confirm the fish ploidal level and to analyze changes in blood cells (contained in this paper). It was found that the percentage of erythrocytes with segmented nuclei in triploid fish was $19.1 \%$ and was significantly higher $(P<0.05)$ than that in diploid fish $(0.3 \%)$. In addition, the number of pathologically cleaved lymphocytes was significantly greater $(P<0.05)$ in $3 \mathrm{n}$ brook trout $(1.5 \%)$ than in diploid fish $(0.8 \%)$. Triploid brook trout blood had a higher percentage of granulocytes with a greater number of segments in a nuclei $(\geq 5)$ compared to diploid trout blood. This shift to the right concerning the granulocytes was not accompanied by changes typical for cell ageing, e.g. vacuolization. A tendency toward nuclear segmentation in blood cells has been suggested as characteristic for the triploid brook trout.

Erythrocyte nuclei, granulocyte nuclei, hypersegmentation, triploids, diploids

The induction of triploids may be beneficial to salmonid aquaculture. Production of non-maturing fishes by triploidization omits problems with sexual maturation responsible for significant losses in the production cycle. Growth rate of triploid fish and food conversion rate were better as compared with diploids because of sterility in triploids (Boulanger 1991). McKay et al. (1992) investigated the influence of triploid induction on survival of brook trout Salvelinus fontinalis (Mitchill) and tiger trout (the interspecific cross of brook trout and brown trout Salmo trutta L.), and observed both reduced survival rate of uneyed egg stage and higher survival of older triploid fish.

Total blood haemoglobin ( $\mathrm{Hb})$ content and mean cellular hemoglobin concentration (MCHC) were lower in triploid Atlantic salmon Salmo salar L. than in the diploid one (Benfey and Sutterlin 1984). According to Cogswell et al. (2002) triploid Atlantic salmon had lower erythrocyte count but total blood $\mathrm{Hb}$ and $\mathrm{MCHC}$ were significantly higher than in diploids. No significant difference in $\mathrm{Hb}$ level was observed between triploid and diploid brook trout although erytrocyte number in triploids was lower (B enfey and Biron 2000). In triploid tench Tinca tinca L. both Hb content and erythrocyte count were decreased (Svobodová et al. 1998). There is a question if any triploid fish suffer from anemia. On the other hand the triploid rainbow trout Oncorhynchus mykiss $\times$ coho salmon Oncorhynchus kisutch hybrids showed a higher resistance against IHN virus, which is responsible for severe losses in salmonid species aquaculture (Pars on s et al. 1986).

Address for correspondence:

Dr. Teresa Własow

Department of Evolutionary Genetics,

University in Olsztyn

Fax: +4889523375

lasow@uwm.edu.pl

0-718 Olsztyn -Kortowo, Poland

htp://www.vfu.cz/acta-vet/actavet.htm 
Woznicki and Kuzminski (2002) searching for simple method of ploidy identification find, that increase of chromosome number was correlated to increase of erythrocyte nucleus major axis in triploid brook trout. In blood smears of examined brook trout (Woznicki and Kuzminski 2002) some alterations in erythrocytes and white blood cells of triploid fish were noticed. The results of these observations are presented in this paper.

\section{Materials and Methods}

Fish used for this study were cultured in Salmonid Research Department in Rutki (Institute of Inland Fisheries in Olsztyn, Poland). Both diploids ( $2 n$ ) and triploids ( $3 n$ ) came from the same lot of eggs. Triploid brook trout Salvelinus fontinalis (Mitchill) were obtained by using hydrostatic pressure shock of $9500 \mathrm{psi}\left(65.5 \times 10^{3} \mathrm{kPa}\right)$ for 5 min applied to eggs $20 \mathrm{~min}$ after fertilization at $10^{\circ} \mathrm{C}$ (Deeley and B enfey 1995). The diploid (control - $2 \mathrm{n}$ ) received no pressure shock and triploid fingerlings were reared in two circular tanks under trout farming technology at the same conditions. Fish expected as triploids (30 specimens) and diploids ( 15 specimens) were used for preparing blood smears. Simultaneously chromosome preparations and the erythrocyte nuclei major axis measurements (Woznicki and Kuzminski 2002) were done in order to confirm fish ploidy. Differential cell counts were made under a 1000 $\times$ magnification. About 300-550 red cells and 200-300 white cells from two slides for every fish were counted. Photos were taken with Nikon Optiphot 2 using a Multiscan programme. Chi-square test was used to evaluate the differences in proportion of "abnormal" to normal erythrocytes and leukocytes in triploid and diploid trout.

\section{Results and Discussion}

The nuclei of erythrocytes of triploid brook trout were elongated: 8.2-10.6 $\mu \mathrm{m}$ for $3 \mathrm{n}$ and 5.9-8.5 $\mu \mathrm{m}$ for $2 \mathrm{n}$ according to Woznicki and Kuzminski (2002). Some of them exhibited abnormal nuclear changes. The nuclei were divided into two rather equal parts (Plate XIV, Fig. 1A). Such regular division of nuclei of mature erythrocytes is defined according to Yokote (1982) as segmentation. The number of erythrocytes with nuclear segmentation was significantly higher $(P<0.05)$ in triploids than diploids (Table 1$)$. Segmentation of erythrocytic nuclei in triploid and diploid brook trout was demonstrated by Benfey (1999) in his interesting review but there was no information about statistically confirmed difference in proportion of this phenomenon in both groups of fish. Red cells with divided nuclei occurred in folic acid deficient coho salmon Oncorhynchus kisutch (S mith 1968). The phenomenon of such aberration of nuclei and presence of large (macrocytic) erythrocytes could be caused by impairment of folic acid dependent replication of DNA in red cells nuclei (S mith 1968).

Table 1

Comparison of blood cells counts in diploid and triploid brook trout (Salvelinus fontinalis (Mitchill)

\begin{tabular}{|lcc|}
\hline Blood cells & Diploids \% & Triploids \% \\
\hline Erythrocytes - normal cells & 99.7 & 80.9 \\
Erythrocytes - with segmented nuclei & 0.3 & 19.1 \\
Lymphocytes - normal cells & 99.2 & 98.5 \\
Lymphocytes - cleaved forms & 0.8 & 1.5 \\
\hline
\end{tabular}

In folic acid deficient coho salmon division of erythrocyte nucleus into small lobes known as fragmentation (Yokote 1982) was common. In examined 3n brook trout nuclear fragmentation, amitosis of nuclei and division of red blood cells (Plate XIV, Fig. 1B) were not so often observed. Small red blood cells without nuclei called erythroplastids and presence of micronuclei inside erythrocytes (Fig.1B) were rarity.

Pathologically cloven lymphocytes (Fig.1A) were more often present in triploid brook trout than in diploid ones (Table $1, P<0.05$ ). Statistically significant increase in number of cloven lymphocytes of carp after a 10-week exposure to ammonia was connected with depression of lymphoid tissue and limitation of the defense mechanism (Wlasow et al. 1990). There was no evidence for lymphoid cells supression in the case of $3 n$ brook trout. 


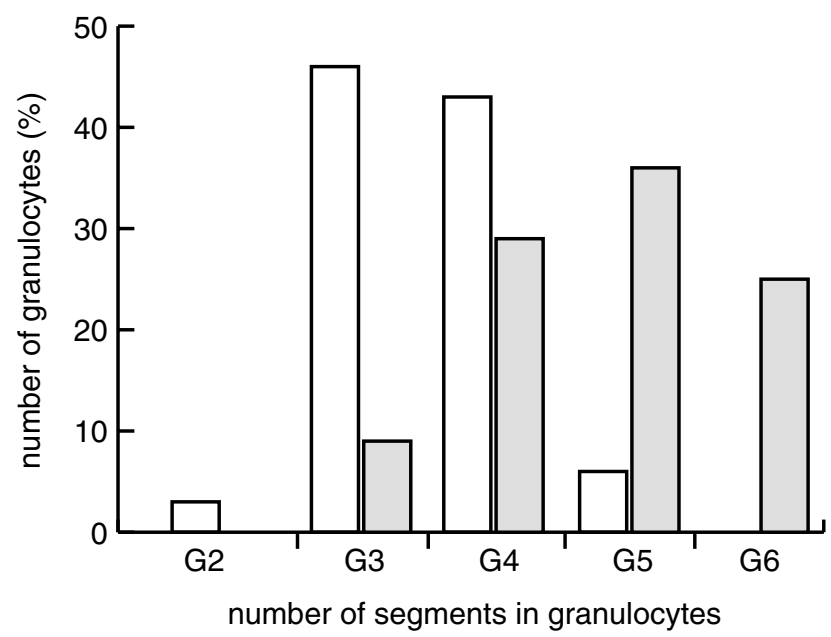

Fig. 2. Comparison of granulocytes segmentation level in diploid and triploid brook trout. G2-G6 - granulocytes with 2 to 6 nuclear lobes. Black columns represent $3 \mathrm{n}$ and white columns represent $2 \mathrm{n}$ brook trout

In triploids compared to diploid brook trout there was significantly higher average number of multi-lobed nuclear granulocytes (Fig. 1C, Fig. 2, $P<0.05$ ). In mammals, older granulocytes have multi-lobed nuclei. In $3 \mathrm{n}$ brook trout this phenomenon can be interpreted as due to ageing of granulocytes, however, typical processes of ageing such as cytoplasm vacuolisation were not observed. Additionally there is species specific "pattern" of nuclear lobes in granulocytes of fish (J o s hi 1980). But no attention has been paid to "ploidy specific pattern" of granulocytic nuclei until now.

The increase of frequency of granulocytes with higher number of nuclear lobes (hypersegmented) in humans is known as a shift to the right and occurs in pernicious anemia (Platt 1979). This disease is connected with macrocytic anemia, leucopenia and presence of macro-granulocytes and demonstrated by numerous morphological abnormalities of the chromosomes (Platt 1979). Another disorder in human neutrophils segmentation is lack of lobes in Pelger-Huet anomaly transmitted by a non-sex linked dominant gene.

In the present paper we found that significantly higher rate of segmented red blood cells nuclei $(P<0.05)$ was found in triploid brook trout induced by the hydrostatic pressure shock, compared to their intact (not shocked) diploid siblings. Our results suggested that also granulocyte pattern could be connected with polyploidy in fishes. There is a question if such nuclear pattern reflects any functional depression or mobilization of granulocytes. Another task is to test the influence of some technical parameters (time and duration of shock) of polyploidization on the blood cells of triploid brook trout. This problem will be the goal of the next study (Własow et al. in press).

\section{Alterace krevních buněk triploidního sivena amerického Salvelinus fontinalis (Mitchill)}

Předmětem experimentu byly krevní buňky pocházejících $\mathrm{z}$ diploidních (2n) a triploidních (3n) sivenů amerických Salvelinus fontinalis (Mitchill). Obě diploidní a triploidní ryby pocházely ze stejné skupiny jiker. Triploidní siveni američtí byli získáni z jiker 20 minut po oplodnění při teplotě $10^{\circ} \mathrm{C}$ vystavením 5minutovému šoku hydrostatického tlaku 9500 psi $\left(65,5 \cdot 10^{3} \mathrm{kPa}\right)$. Diploidní ryby nebyly vystaveny žádnému šoku. 3n a 2 n plůdek sivena amerického byl odchován za stejných podmínek (prostředí, 
potrava) v paralelních nádržích. Byly provedeny krevní nátěry, které v kombinaci s preparovanými chromozomy, byly použity k ověření ploidie a $\mathrm{k}$ analýze změn v krevních buňkách (zahrnutých v tomto článku). Bylo zjištěno, že procento erytrocytů s rozděleným jádrem u triploidních ryb bylo $19.1 \%$ a bylo signifikantně vyšší $(P<0.05)$ než u diploidních ryb $(0.3 \%)$. Navíc, množství patologicky změněných lymfocytů bylo signifikantně vyšší $(P<0.05)$ u 3 n sivenů amerických $(1.5 \%)$ než u diploidních ryb $(0.8 \%)$. Krev triploidního sivena amerického obsahovala vyšší procento granulocytů s větším množstvím jaderných segmentů $(\geq 5)$ ve srovnání s diploidními. Tento posun doprava týkající se granulocytů nebyl doprovázen změnami typickými pro buněčné stárnutí, např. vakuolizace. Tendence k jaderné segmentaci v krevních buňkách bylo navrženo jako charakteristické pro triploidní siveny americké.

\section{Acknowledgements}

This study was supported by grant number 080302.0205 University in Olsztyn and by the grant 3 PO6Z 00725 of the Polish Scientific Research Committee.

\section{References}

BENFEY, TJ 1999: The physiology and behaviour of triploid fishes. Rev Fish Sci 7: 39-67

BENFEY, TJ, SUTERLIN, AM 1984: The haematology of triploid landlocked Atlantic salmon Salmo salar L. J Fish Biol 24: 333-338

BENFEY, TJ, BIRON, M 2000: Acute stress response in triploid rainbow trout (Oncorhynchus mykiss) and brook trout (Salvelinus fontinalis). Aquaculture 184: 167-176

BOULANGER, Y 1991: Performance comparison of all-female, diploid and triploid brook trout. In: Pepper VA (Ed.): Proceedings of the Atlantic Canada workshop on methods for the production of non-maturing salmonids, Can Tech Rep Fish Aquat Sci 1789: 111-119

COGSWELL, AT, BENFEY, TJ, SUTTERLIN, AM 2002: The haematology of diploid and triploid transgenic Atlantic salmon (Salmo salar). Fish Physiol Bioch 24: 271-277

DEELY, MA, BENFEY, TJ 1995: Learning ability of triploid brook trout. J Fish Biol 46: 905-907

JOSHI, BD 1980: Arneth counts of the granulocytic leucocytes of 33 species of fresh water teleosts. Ind J Anim Res 14: 43-47

PARSONS, JE, BUSH, RA, THORGAARD, GH, SCHERER, PD 1986: Increased resistance of triploid rainbow trout $\mathrm{x}$ coho salmon hybrids to infectious haematopoietic necrosis virus. Aquaculture 57: 337-343

MC KAY, LR, IHSSEN, PE, MC MILLAN, I 1992: Early mortality of tiger trout (Salvelinus fontinalis x Salmo trutta) and the effects of triploidy. Aquaculture 102: 43-54

PLATT, WR 1979: Colour atlas and textbook of haematology. J.P. Lippincott Company, Philadelphia, Toronto. pp. 644

SVOBODOVÁ, Z, KOLÁŘOVÁ, J, FLAJŠHANS, M: 1998. The first finding of the differences in complete blood count between diploid and triploid tench, Tinca tinca L. Acta vet Brno 67: 243-248

SMITH, CE 1968: Haematological changes in coho salmon fed a folic acid deficient diet. J Fish Res Bd Can 25 : $151-156$

WŁASOW, T, DABROWSKA, H, ZIOMEK, E 1990: Haematology of carp in prolonged sublethal ammonia intoxication. Pol Arch of Hydrobiol 37: 429-438

WŁASOW, T, KUZMINSKI, P, WOZNICKI, P: The influence of different technical methods of triploid induction on the blood picture of brook trout Salvelinus fontinalis (Mitchill). In press

WOZNICKI, P, KUZMINSKI, H 2002: Chromosome number and erythrocyte nuclei length in triploid brook trout (Salvelinus fontinalis). Caryologia 55: 295-298

YOKOTE, M 1982: Vascular system. In: Hibiya T. (ed.) An atlas of fish histology normal and pathological features, Gustav Fischer Verlag, Stuttgart, pp. 58-73 
Plate XIV

Wlasow T. et al.: Blood Cell Alteration ... pp. 115-118

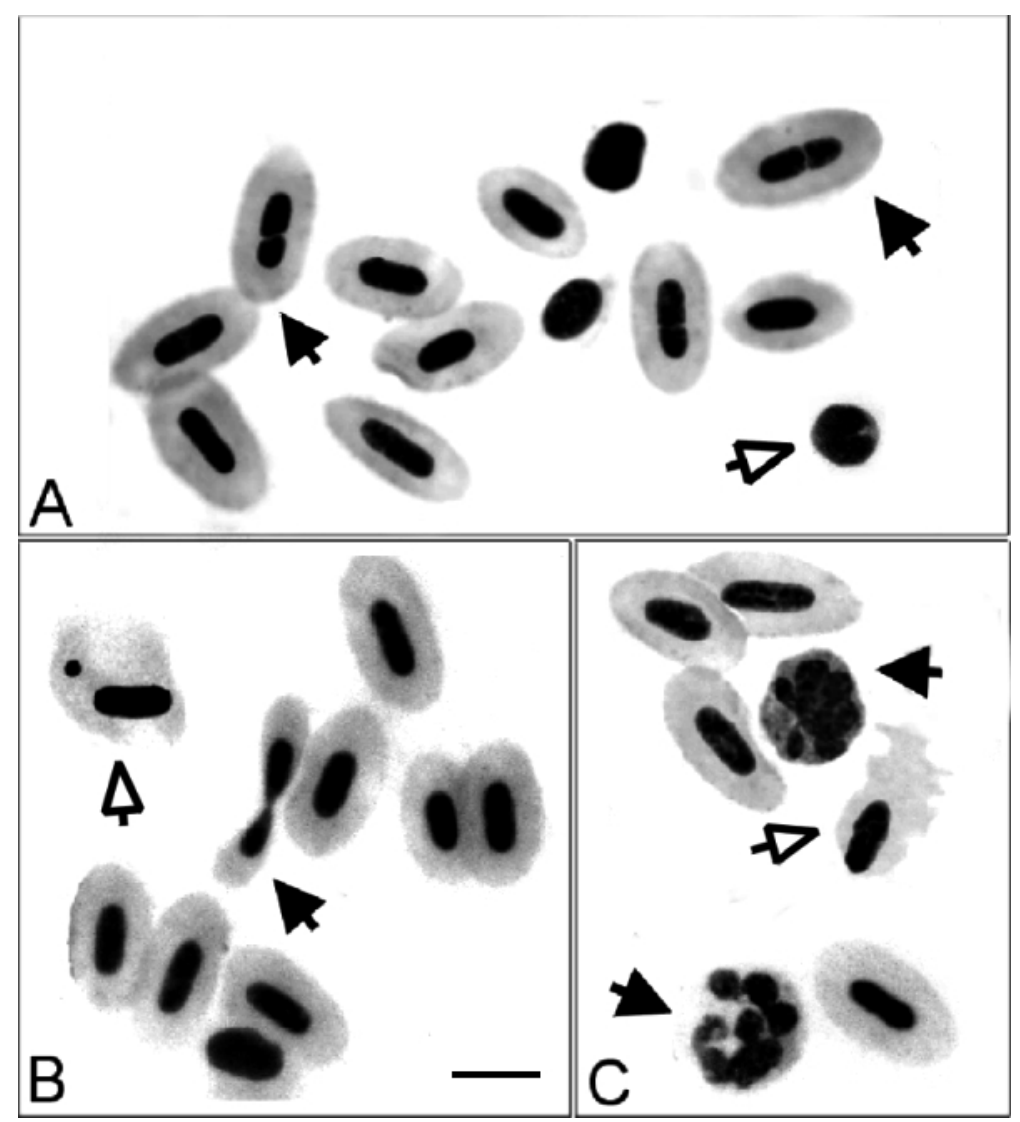

Fig.1. Blood cells alteration in triploid brook trout. A: The segmentation of nuclei in erythrocytes (black arrows), small cleaved lymphocyte (white arrow). B: Amitosis of erythrocyte (black arrow), erythrocyte with dislocated nucleus and one micronucleus (white arrow). C: Two hypersegmented granulocytes (black arrows); pycnotic nucleus of erythrocyte undergoing extrusion (white arrow). Bar equals $10 \mu \mathrm{m}$ 